\title{
Mindeord for Per Ole Träskman (1944-2019), Dr. Juris
}

\author{
Af Anette Storgaard
}

Nordisk strafferet og kriminologi mistede en betydningsfuld personlighed, da Per Ole Träskman den 22. juli afgik ved døden efter kort tids sygdom.

Per Ole kom til verden i en finsk landbofamilie i 1944. Det har formentlig ikke ligget i kortene, at han allerede som 33 årig skulle opnå den juridiske doktorgrad og blive professor i straffeog procesret ved universitetet i Helsingfors som 36-årig. I 1995 blev Per Ole efter et kort ansættelsesforløb på CBS i København professor i strafferet ved Lunds universitet. Her var han dekan for det juridiske fakultet i perioden 20002009 og gik formelt på pension i 2016. Men Per Ole spillede en aktiv rolle i hele det nordiske fagmiljø lige til sin alt for tidligere død som 75-årig.

Per Ole har igennem årene både skrevet og holdt foredrag om stort set alle de »tunge« strafferetlige og procesretlige emner. Uanset hvor mange der nævnes, vil nogle blive overset, men blandt de emner, der har fyldt meget i de nordiske fagmiljøer, er en række problemstillinger fra strafferettens almindelige del, international og EU-strafferet, miljøstrafferet, narkotika, den strafferetlige regulering af seksuelle ydelser og seksualdelikter samt anklagemyndighedens rolle og opgaver.

Lynkarriere og en usædvanligt vidtfavnende videnskabelig produktion kunne hænge sammen med en person, der har nok i sin egen visdom. Men det er ikke tilfældet her. Per Ole Träskman var altid stærkt engageret i det nordiske faglige miljø. Fra 1970 til 1973 var han den daglige leder af sekretariatet for Nordisk Samarbejdsråd for Kriminologi. Det var i en periode, hvor Rådet havde adresse i Helsingfors, og Inkeri Anttila var formand. Sidenhen sad han som finsk redaktør for Nordisk Tidsskrift for Kriminalvidenskab i knap 20 år fra 1979 til og med 1996. Helt frem til 2018 findes der kun få årgange af nærværende tidsskrift, som Per Ole ikke har bidraget til med artikler og indsigtsfulde boganmeldelser.

Som faglig debattør - på skrift og i tale - havde Per Ole en sjælden styrke. Man har aldrig oplevet ham have behov for at bidrage til den - i videnskabelige 
kredse ikke helt sjældne - disciplin, der går ud på at hævde sig selv igennem nedgørelse af andre. Han kunne være stille så længe, at man kom i tvivl, om han stadig hørte efter, for pludselig at fremlægge sin klokkeklare analyse af problemet. Stilfærdigt, men knivskarpt blev både fagfæller, medier og beslutningstagere præsenteret for argumenter, der ikke kunne modsiges og ofte blev understøttet af en indlejring i en aktuel samfundspolitisk ramme.

Der hersker ikke tvivl om Per Ole Träskmans formelle faglige anerkendelse. Han var æresdoktor ved Aabo Universitet i Finland og Ho Chi Minh-universitetet i Vietnam, medlem af akkrediteringsnævnet for de juridiske uddannelser i Danmark samt medlem af utallige bedømmelsesudvalg på alle videnskabelige niveauer $i$ alle de nordiske lande.

Mindre iøjnefaldende, men af stor reel betydning, er den store og uselviske indsats for at opmuntre unge forskere. I 1996 tog Per Ole initiativ til en gang om året at afholde en nordisk strafferetsworkshop. Konceptet var enkelt. De nordiske lande skulle på skift stå for arrangementet, og alle ph.d.-studerende inden for strafferet og kriminologi var inviteret sammen med deres vejledere. På skift fik de ph.d.-studerende mulighed for at præsentere de igangværende projekter og modtage inspiration igennem efterfølgende drøftelser med både jævnbyrdige og mere erfarne kolleger. Disse arrangementer finder stadig sted en gang om året og spiller en stor rolle for de unge.

Per Ole Träskman nød stor anerkendelse og var ofte inviteret som ekspert eller foredragsholder, men han var ikke en person, der opsøgte rampelyset og berømmelsen. Han gik gerne derhen, hvorfra der blev rakt ud efter hans erfaring og vid, og han øste rundhåndet ud uden at forvente noget til gengæld eller behov for selvhævdelse. Jeg har personligt kendskab til, at Per Ole loyalt har brugt timer på at hjælpe unge forskere med at forme et holdbart projekt på grundlag af den unges egne ideer - ikke med den hensigt at styre det i en bestemt retning. Jeg ser det også som udtryk for vilje og evne til at understøtte faglig udvikling, at Per Ole lagde mange kræfter i en samarbejdsaftale imellem Lunds Universitet og Ho Chi Minh-universitetet og i en årrække besøgte Vietnam og gennemførte forskeruddannelse dér.

Første gang jeg mødte Per Ole Träskman, var i midten af 1980-erne i det hedengangne DDR. Jeg var en eventyrlysten studerende på studieophold, men kollegerne i strafferet og kriminologi på Humboldt Universitetet i Berlin havde rakt ud efter den unge finske strafferetsprofessor, fordi de havde brug for fagligt medog modspil uden forudfattet vestlig fordømmelse.

Der gik mange år, før jeg mødte Per Ole igen. Men jeg genkendte straks den fordomsfrie klogskab, den helstøbte personlighed og den menneskelige varme.

Per Ole Träskman vil blive savnet som kollega og ven. 